\title{
KAPASITAS GURU PROFESIONAL DI PENDIDIKAN DASAR ISLAM
}

\author{
Andi Prastowo \\ (Dosen Prodi.PGMI FITK UIN Sunan Kalijaga Yogyakarta)
}

\begin{abstract}
Professional needs of teachers in the Elementary School is a very buge necessity, moreover government assigned National Standards of Education and teacher certification. However, the various efforts made by the government has been not significant results yet although the government's efforts can't be considered pity. The one reason is because it still seems unclear concept of professional teachers in Elementary School. From the results of this literature study, it was found that the required professional teachers especially in Elementary School must have a capacity of four, namely intellectual and research, spiritual, moral and ethic capacity, and last is emotional capacity.
\end{abstract}

Keywords: quality of education, certification, capacity, professional teachers.

\section{A. PENDAHULUAN}

Tuntutan dan kebutuhan guru yang profesional di Madrasah Ibtidaiyah sangat besar. Banyak program juga telah diupayakan untuk memperbaiki kondisi tersebut. Namun, selama ini realitas di lapangan menunjukkan bahwa kualitas guru-guru di Madrasah Ibtidaiyah masih kurang profesional, misalnya kualifikasi pendidikannya tidak linier, bukan sebagai pekerjaan utama tetapi pekerjaan sampingan, dan lain sebagainya, atau hanya sebagai status. ${ }^{1}$ Apalagi jika dibandingkan dengan kualiltas guru di Sekolah Dasar, bedanya akan jauh. Diperparah dengan kondisi madrasah yang didominasi oleh lembaga pendidikan yang dikelola oleh masyarakat kelas menengah ke bawah, bukan lembaga yang dikelola pemerintah. Hal ini semakin memperparah kondisi tersebut.

Persoalan di atas memunculkan pertanyaan besar, apakah kualitas guru di Madrasah Ibtidaiyah tidak bisa dikembangkan? Namun, kiranya tidak seperti itu. Manusia pada hakikatnya adalah makhluk yang dapat dididik dan dapat mendidik. Sebagaimana diungkapkan Djumransyah dan

${ }^{1}$ Andi Prastowo, "Profesionalitas Seksi Mapenda di Kabupaten Sleman dalam Peningkatan Mutu Pendidikan di Madrasah Ibtidaiyah", Tesis, Tidak Diterbitkan, Yogyakarta: Program Pascasarjana Magister Pendidikan Guru Madrasah Ibtidaiyah UIN Sunan Kalijaga Yogyakarta, 2010.

LITERASI, Volume. IV, No. 2 Desember 2013 
Amrullah, karena potensi manusia yang dapat dididik dan dapat mendidik itulah manusia berbeda dengan makhluk yang lainnya. Bahkan, dengan potensi inilah manusia memiliki predikat sebagai makhluk yang mulia (Q.S At-Tin $(95: 4){ }^{2}$

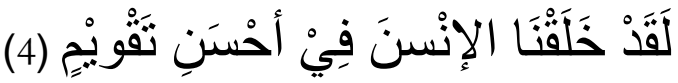
baiknya.

Sesunggubnya Kami telah menciptakan manusia dalam bentuk yang sebaik-

Sebagai makhluk yang memiliki potensi dapat mendidik, maka menjadi guru yang profesional bukan pekerjaan yang terlalu sulit dan mustahil dicapai oleh manusia. Yang dibutuhkan adalah pemberdayaan dan pengembangan atas potensi-potensi baik tersebut. ${ }^{4}$ Sebagaimana hal ini dijelaskan dalam sebuah konsep hadits dengan istilah fitrah. Seperti dalam hadits yang diriwayatkan Imam Muslim No. 4803 yang memiliki derajat sabih baik dari segi sanad maupun matan-nya berikut ini:

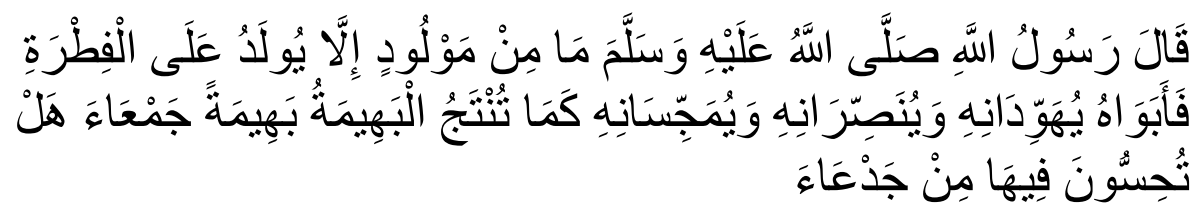

Artinya:

"Rasulullah shallallahu 'alaihi wasallam telah bersabda: 'Seorang bayi tidak dilahirkan (ke dunia ini) melainkan ia berada dalam kesucian (fitrah). Kemudian kedua orang tuanyalah yang akan membuatnya menjadi Yahudi, Nasrani, ataupun Majusi -sebagaimana hewan yang dilahirkan dalam keadaan selamat tanpa cacat. Maka, apakah kalian merasakan adanya cacat? '5

${ }^{2}$ H.M. Djumransjah dan Abdul Malik Kamrullah, Pendidikan Islam: Menggali Tradisi, Menegubkan Ekesistensi (Malang: UIN-Malang Press, 2007), hlm. 40-41

${ }^{3}$ Q.S al-Tin (95): 4 dalam Al-Qur'an dan Terjemahannya, Diterj. oleh: Yayasan Penyelenggara Penterjemah/Penafsir Al-Qur'an Revisi Terjemah oleh Lajnah Pentashih Mushaf A-Qur'an Departemen Agama Republik Indonesia, hlm. 598

${ }^{4}$ Toto Suharto, Filsafat Pendidikan Islam Edisi Baru (Yogyakarta: Ar-Ruzz Media, 2011), hlm. 88

${ }^{5}$ H.R. Muslim No. 4803 ini berkualitas sahih baik dari sanad maupun matan. Lihat selengkapnya Soltanera, CD Ensiklopedi Hadits Kitab 9 Imam (Lidwa Pustaka, 2010-2011). Program hadits ini merupakan proyek terjemahan resmi dari software asli dari Kitab Kutubut Tis'ah yaitu CD Mausu'ah Hadis Syarif Versi 2.00, Dar us Salam Publication, Inc, 1991-1997. 
Dalam realitas pendidikan Islam saat ini, terutama di Madrasah Ibtidaiyah, menurut A. Malik Fadjar, "...kita masih kekurangan guru, kalau tenaga pengajar banyak, tetapi tenaga guru masih sangat langka."6 Dan, sesungguhnya karena kondisi tersebut telah diupayakan berbagai cara untuk meningkatkan profesionalisme guru agar dapat mendongkrak mutu pendidikan. Seperti di antaranya melalui program peningkatan kualifikasi pendidikan guru, program penyetaraan dan sertifikasi, 7 program pelatihan terintegrasi berbasis kompetensi, program supervisi pendidikan, program pemberdayaan MGMP, simposium guru, program pelatihan tradisional lainnya, membaca dan menulis jural atau karya ilmiah, berpartisipasi dalam pertemuan ilmiah, melakukan penelitian (PTK), magang, mengikuti berita aktual dari media pembelajaran, berpartisipasi dan aktif dalam organisasi profesi, dan menggalang kerjasama dengan teman sejawat. ${ }^{8}$

Namun, sayangnya meskipun berbagai upaya tersebut telah dilakukan, dalam kurun waktu hampir satu dasawarsa terakhir mutu pendidikan nasional pun masih belum menunjukkan peningkatan kualitas yang menggembirakan.9 Kondisi ini tampak ditunjukkan salah satunya karena masih carut-marutnya pemahaman dasar tentang konsep guru profesional itu sendiri, termasuk guru madrasah ibtidaiyah, dalam dunia pendidikan. Dalam khasanah pendidikan Islam, sesungguhnya konsep dasar guru MI profesional bisa merujuk pada al-Qur'an maupun al-Hadits melalui

${ }^{6}$ H. Muhaimin, "Reorietasi Pengembangan Guru", dalam H. Mudjia Rahardjo (Ed.), Quo Vadis Pendidikan Islam: Pembacaan Realitas Pendidikan Islam, Sosial dan Keagamaan (Malang: UIN-Malang Press, 2006), hlm. 101

${ }^{7}$ Proses pemberian sertifikat pendidik kepada guru atau dosen yang telah memenuhi syarat tertentu. Dan, oleh karenanya guru atau dosen berhak mendapatkan peningkatan ksejahteraan berupa gaji yang pantas dan tunjangan profesi. Baca Jamal Ma'mur Asmani, 7 Tips Cerdas dan Efektif Lulus Sertifikasi Guru (Yogyakarta: Diva Press, 2010), hlm. 20-21

${ }^{8}$ Udin Syaefudin Sa'ud, Pengembangan Profesi Guru (Bandung: Alfabeta, 2009), hlm. 103-111

9 Seperti diungkapkan Bahrudin, berdasarkan laporan PBB tahun 2004, kualitas pendidikan Indonesia (Education Index $=0,80)$ berada di bawah Vietnam $(0,82)$ atau terendah di antara negara-negara ASEAN lainnya. Terlebih lagi dari penelitiannya UNESCO-OECD dalam Programme of International Student Assessment (PISA), kecakapan membaca anak-anak Indonesia (usia 15 tahun) sangatlah rendah (peringkat 39 dari 41 negara yang diteliti). Lihat Bahrudin, "Pendidikan untuk Keberdayaan Desa", dalam A. Ferry T. Indratno, Kurikulum yang Mencerdaskan: Visi 2030 dan Pendidikan Alternatif (Jakarta: Kompas Media Nusantara, 2008), hlm. 159 
indikasi pada istilah-istilah seperti mu'allim, murabbiy, ursyid, dan, mu'addib. 10

Untuk itu, dalam kerangka studi mengenai konsep kapasitas guru MI profesional pada artikel ini akan dikaji secara lebih mendalam pokok permasalahan di atas dengan beberapa rumusan masalah sebagai berikut: pertama, apakah konsep dasar guru profesional yang bisa dibangun dari berbagai istilah tentang "guru" dalam Islam yang meliputi mu'allim, murabbiy, ursyid, dan, mu'addib? Kedua, bagaimanakah karakteristik guru profesional? Ketiga, bagaimanakah implikasi konsep guru profesional untuk pengembangan profesionalisme guru pada madrasah ibtidaiyah? Dengan demikian melalui kajian ini diharapkan akan ditemukan konsep dasar yang kokoh tentang kapasitas guru MI profesional. Yang kemudian hal itu dapat memberikan pemahaman tentang pola pengembangan guru MI profesional yang holitistik dan integralistik.

\section{B. METODE PENELITIAN}

Studi untuk artikel ini adalah termasuk dalam kategori penelitian literer (kepustakaan). Adapun jenis penelitian yang digunakan adalah penelitian kualitatif yang menggunakan teknik analisis isi dengan pendekatan hermeneutik post strukturalisme. Maksudnya, kajian ini akan diarahkan dan dilakukan dengan mengembangkan meaning of creativity dari pemaknaan bahasa yang klasik tentang mu'allim, murabbiy, ursyid, dan, mu'addib. Di mana cara kerjanya, teks maupun sesuatu yang dilisankan itu akan didekonstruksi dari pemahaman konvensional ke pemahaman baru. ${ }^{11}$

Sumber data yang akan digunakan adalah buku-buku ataupun tulisantulisan yang terkait dengan tema yang diangkat dalam penelitian ini. Sedangkan data penelitiannya berupa pemikiran para filosof tentang berbagai istilah yang terkait dengan guru seperti mu'allim, murabbiy, ursyid, dan, mu'addib yang tertuang dalam berbagai tulisan-tulian baik di buku, artikel, maupun jurnal. Kemudian juga akan dikaji pemikiran para tokoh pendidikan tentang pengembangan profesionalisme guru madrasah ibtidaiyah.

${ }^{10}$ H. Muhaimin, "Reorietasi Pengembangan Guru", dalam H. Mudjia Rahardjo (Ed.), Quo Vadis Pendidikan Islam: Pembacaan Realitas Pendidikan Islam, Sosial dan Keagamaan (Malang: UIN-Malang Press, 2006), hlm. 101

11 Noeng Muhadjir, Metodologi Penelitian: Paradigma Positivisme Objektif, Phenomenologi Interpretif, Logika Bahasa Platonis, Chomskyist, Hegelian \& Hermeneutik, Paradgma Studi Islam Matematik Recursion, Set-Theory \& Structura Equation Modelling dan Mixed Edisi VI Pengembangan 2011 (Yogyakarta: Rake Sarasin, 2011), hlm. 317-318 
Untuk melakukan kajian ini, maka prosedur kerjanya peneliti akan mengkoleksi data tentang konsep guru yang meliputi mu'allim, murabbiy, ursyid, dan, mu'addib dari berbagai bahan pustaka yang relevan. Dari langkah pertama ini, kemudian dilanjutkan dengan melakukan analisis intertekstualitas secara interpretatif yang diupayakan untuk memunculkan meaning of creativity dari konsep guru dalam pendidikan Islam yang selama ini ada di atas. Setelah itu, maka peneliti akan memadukan konsep guru profesional yang muncul dari konsep mu'allim, murabbiy, ursyid, dan, mu'addib tersebut dengan upaya pengembangan profesionalisme guru dalam pendidikan Islam sehingga diperoleh landasan yang kuat dan tegas. Terakhir, melakukan abstraksi dan penyimpulan terhadap konsep guru profesional dan pengembanganya dalam pendidikan Islam. Dengan demikian, dapat diperoleh definisi operasional tentang konsep guru profesional dan pengembanganya dalam pendidikan Islam yang dapat diterapkan di ranah praksis.

\section{PEMBAHASAN DAN ANALISIS}

1. Makna mu'allim, murabbiy, mursyid, dan, mu'addib dalam Pendidikan Islam

Pada pembahasan ini akan dikembangkan suatu meaning of creativity tentang guru profesional dari konsep-konsep klasik yang selama ini dipakai dalam pendidikan Islam, yaitu mu'allim, murabbiy, mursyid, dan, mu'addib. Dalam teks al-Qur'an dan al-Hadits, istilah-istilah tersebut dijelaskan dari akar kata sebagai berikut:

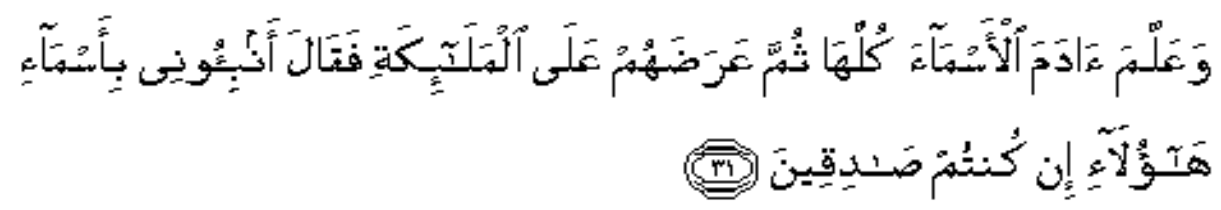

Dan Dia mengajarkan kepada Adam nama-nama (benda-benda) selurubnya, kemudian mengemukakannya kepada para Malaikat lalu berfirman: "Sebutkanlah kepada-Ku nama benda-benda itu jïka kamu memang orang-orang yang benar!"12

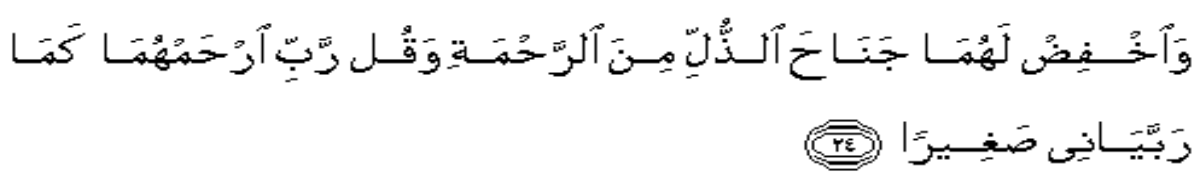

12 Q.S. Al-Baqarah (2): 31 dalam Al-Qur'an ... hlm. 7

LITERASI, Volume. IV, No. 2 Desember 2013 
Dan rendabkanlah dirimu terhadap mereka berdua dengan penub kesayangan dan ucapkanlab: "Wahai Tubanku, kasibilah mereka keduanya, sebagaimana mereka berdua telah mendidik aku waktu kecil"." ${ }^{13}$
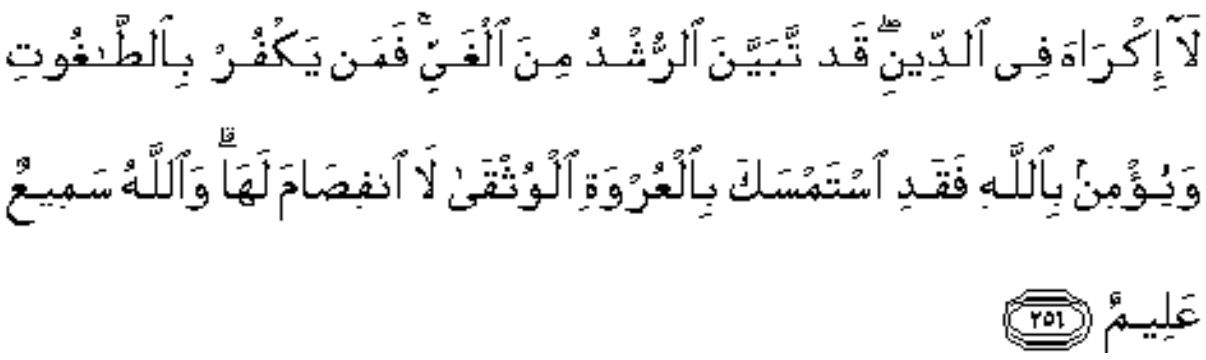

Tidak ada paksaan untuk (memasuki) agama (Islam); sesunggubnya telah jelas jalan yang benar daripada jalan yang sesat. Karena itu barang siapa yang ingkar kepada Thaghut dan beriman kepada Allah, maka sesunggubnya ia telab berpegang kepada bubul tali yang amat kuat yang tidak akan putus. Dan Allah Maba Mendengar lagi Maha Mengetabui. ${ }^{14}$

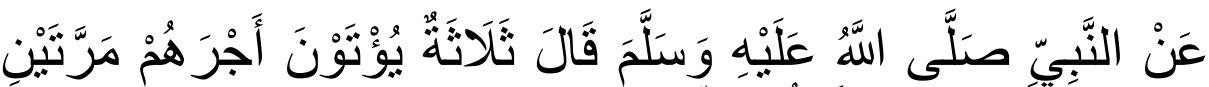

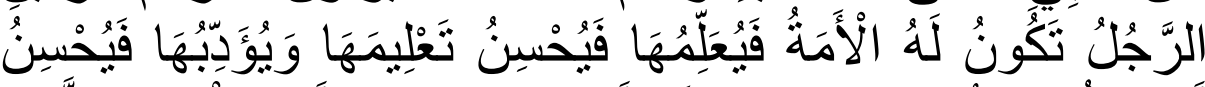

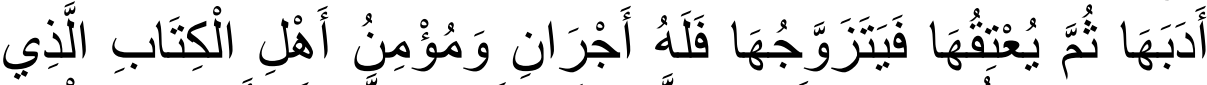

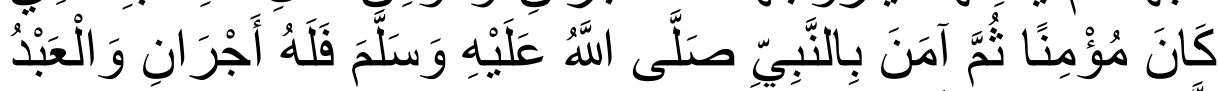

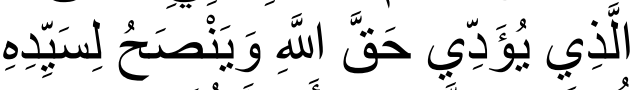

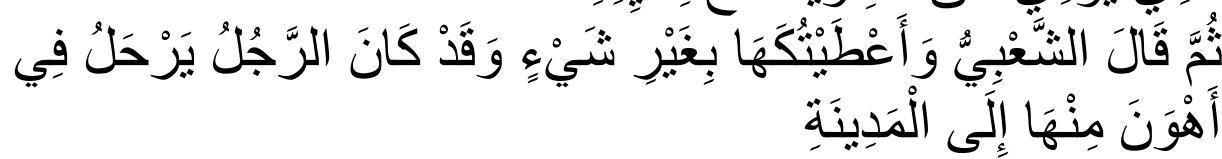

Telah bercerita kepada kami Mubammad bin Muqatil telah mengabarkan kepada kami 'Abdullah telah mengabarkan kepada kami Shalih bin Hayyi bahwa ada seorang laki-laki penduduk. Khurasan berkata kepada asy-Sya'biy, Abu Burdah telah mengabarkan kepadaku dari Abu

13 Q.S. Al-Israa (17): 24 dalam Al-Qur'an..., hlm. 285

${ }^{14}$ Q.S. Al-Baqarah (2): 256 dalam Al-Qur'an..., hlm. 43 
Musa Al Asy'ariy radliallabu 'anbu berkata, Rasulullah shallallabu 'alaibi wasallam besabda: "Jika seseorang mendidik sahaya wanitanya dengan baik. dan mengajarkan ilmu dengan baik kemudian dia membebaskan lalu menikabinya maka baginya dua pahala. Dan bila seseorang beriman kepada 'Isa 'alaibis salam kemudian beriman kepadaku maka baginya dua pahala. Dan seorang sahaya (laki-laki) bila dia bertaqwa kepada Rabbnya dan mentaati tuannya maka baginya dua pabala". ${ }^{15}$

Dari penjelasan di atas dapat diungkap bahwa sesungguhnya guru profesional dalam khasanah pendidikan Islam adalah guru holistik-integralistik. Sebagaimana diperoleh penjelasan dari akar kata istilah mu'allim bahwa seorang guru dituntut untuk mampu menjelaskan hakikat ilmu pengetahuan yang diajarkannya serta menjelaskan dimensi teoritis dan praktisnya dan berusaha membangkitkan siswa untuk mengamalkannya. Dengan demikian, seorang guru dituntut untuk sekaligus melakukan transfer ilmu pengetahuan, internalisasi, serta amaliah (implemetasi). ${ }^{16}$

Kemudian, dari istilah murabbiy, maka guru mengandung tugas yaitu untuk mendidik dan menyiapkan peserta didik agar mampu berkreasi, sekaligus mengatur dan memlihara hasil kreasinya untuk tidak menimbulkan malapetaka bagi dirinya, masyarakat, dan alam sekitarnya. ${ }^{17} \mathrm{Hal}$ ini didasari dari pandangan dasar bahwa Tuhan sebagai rabb al-'alamin dan rab al-nas yakni menciptakan, mengatur dan memelihara alam seisinya termasuk manusia. Manusia sebagai khalifah-Nya ${ }^{18}$ diberi tugas untuk menumbuhkembangkan

${ }^{15}$ H.R. Bukhari No. 3190 ini berkualitas sahih baik dari sanad maupun matan. Hal ini juga dikuatkan dengan hadist-hadits sahih lainnya dari periwayat yang lain yang mengungkapkan hal yang sama yaitu pada Sunan Abi Dawud No. 4481, Musnad Ahmad No. 18777, Sunan an-Nasa'iy No.3292, dan Sunan at-Tirmidziy No. 1035. Lihat selengkapnya Soltanera, CD Ensiklopedi Hadits Kitab 9 Imam (Lidwa Pustaka, 2010-2011). Program hadits ini merupakan proyek terjemahan resmi dari software asli dari Kitab Kutubut Tis'ah yaitu CD Mausu'ah Hadis Syarif Versi 2.00, Dar us Salam Publication, Inc, 1991-1997.

${ }^{16} \mathrm{H}$. Muhaimin, "Reorietasi Pengembangan, hlm. 102

${ }^{17}$ Ibid., hlm. 102-103

${ }^{18}$ Baca Q.S. al-Baqarah (2):30, Q.S. al-An'am (6):165 dalam Al-Qur'an..., hlm. 7 dan 151 
kreativitasnya agar mampu mengkreasi, ${ }^{19}$ mengatur, dan memelihara alam seisinya. ${ }^{20}$

Sementara itu dari istilah mursyid, maka dapat dipahami bahwa seorang guru (mursyid) berusaha menularkan penghayatan (transinternalisasi) akhlak dan atau kepribadiannya kepada peserta didiknya, baik yang berupa etos ibadahnya, etos kerjanya, etos belajarnya, maupun dedikasinya yang serba lillabi ta'ala (yaitu, karena keihklasan semata-mata hanya untuk mengharapkan ridha Allas Swt). Atau dengan kata lain, guru adalah sosok teladan dan panutan maupun konsultan bagi siswanya. ${ }^{21}$

Dan, terakhir, berangkat dari istilah mu'addib maka guru adalah orang yang beradab sekaligus memiliki peran dan fungsi untuk membangun peradaban. ${ }^{22}$ Bahkan dengan merunut penjelasan Djumransjah dan Amrullah bahwa guru dalam konteks pengertian mu'addib maka ia harus mampu menguasai dan mengamalkan ilmu pengetahuannya serta mampu mengajarkan dan memberikan pengasuhan yang berbasis keberadaban. ${ }^{23}$

\section{Karakteristik Guru Holistik-Integralistik sebagai Guru} Profesional di Madrasah Ibtidaiyah

Berdasarkan penjelasan konsep dasar di atas, maka hakikat guru holistik-integralistik di sini adalah perwujudan dari manusia yang paling mulia ${ }^{24}$, utuh, dan memiliki berbagai kelebihan dibanding yang lainnya. ${ }^{25}$ Ia adalah orang yang secara sengaja mampu mengasuh individu atau beberapa individu lainnya, agar mereka dapat tumbuh dan berhasil dalam menjalani hidup. Adalah Muhammad Saw. dan para Rasul lainnya contoh dari guru holistikintegralistik tersebut. Meskipun, dikatakan oleh Moh. Slamet

\section{${ }^{19}$ Baca Q.S. Hud (11):61 dalam Al-Qur'an..., hlm. 229}

${ }^{20}$ H.M. Djumransjah dan Abdul Malik Karim Amrullah, Pendidikan Islam: Menggali "Tradisi”, Menegubkan Eksistensi (Malang: UIN-Malang Press, 2007), hlm. 3637

${ }^{21}$ H. Muhaimin, "Reorietasi Pengembangan, hlm. 104-105

${ }^{22}$ Ibid., hlm. 105

${ }^{23}$ H.M. Djumransjah dan Abdul Malik Karim Amrullah, Pendidikan Islam..., hlm. 36-37

${ }^{24}$ Baca Q.S. al-Tin (95):4 (sesunggubnya Kami telah menciptakan manusia dalam bentuk yang sebaik-baiknya) dalam Al-Qur'an..., hlm. 598

25Baca Q.S. al-Israa' (17):70 (Dan sesunggubnya telah Kami muliakan anak-anak Adam, Kami angkut mereka di daratan dan di lautan, Kami beri mereka rezeki dari yang baikbaik dan Kami lebibkan mereka dengan kelebihan yang sempurna atas kebanyakan makbluk yang telah Kami ciptakan) dalam Al-Qur'an..., hlm. 290 
Untung, pendidik pertama (sebagaimana diyakini umat Islam) adalah Allah Swt., sedangkan Rasul adalah manusia sempurna, insan kamil, yang dipilih Allah untuk menyampaikan wahyu melalui bimbingan dan pendidikan. ${ }^{26}$

Adapun jika diurai lebih lanjut, maka sosok guru holistikintegralistik sebagai guru profesional dalam pendidikan Islam memiliki struktur karakteristik seperti tampak pada Gambar 1.

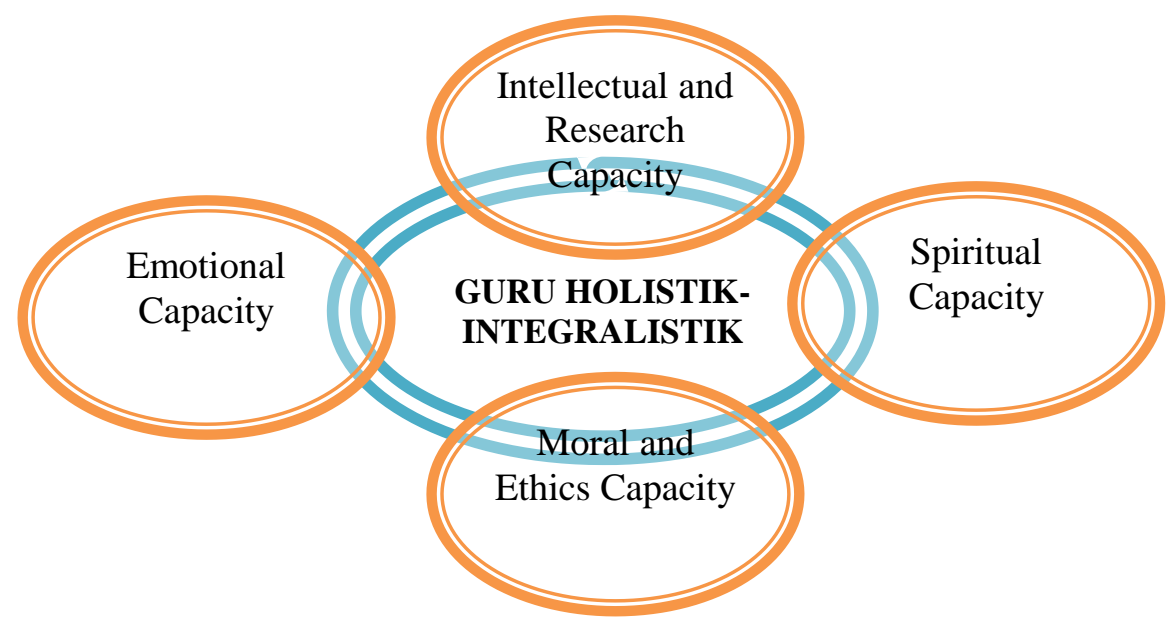

Gambar 1

Karakteristik Guru Holistik-Integralistik sebagai Guru Profesional dalam Pendidikan Islam

Untuk penjelasan bagan karakteristik guru holistik sebagai konsep dasar guru profesional dalam pendidikan Islam dapat diterangkan sebagai berikut: pertama, memiliki intellectual and reasearch capacity (kecakapan intelektual dan peneltian). Jadi seorang guru profesioal harus memiliki penguasaan terhadap ilmu pengetahun baik dari segi filosofis, teoritis maupun praktis. Selain itu, ia juga

${ }^{26}$ Moh. Slamet Untung, Muhammad Sang Pendidik (Semarang: Pustaka Rizki Putra bekerjasama dengan Program Pascasarjana IAIN Walisongo, 2005), hlm. 52-53 
mampu menjadi mediator dan fasilitator bagi siswa untuk lebih banyak mengadakan penelitian, eksperimen di laboraturium, problem solving terhadap masalah-masalah sosial dan sebagainya. Dengan demikian, proses pendidikan yang diciptakannya dapat menghasilkan nilai-nilai positif yang berupa sikap rasional empirik, obyektif-empirik, obyek-matematis, dan profesional. ${ }^{27}$

Kedua, memiliki spiritual capacity (kecakapan spiritual). Dengan demikian guru mampu memiliki etos ibadah, etos kerja, etos belajar, dan dedikasi yang tinggi (serba lillabi ta'ala atau penuh keikhlasan dan ketulusan). Dengan kata lain, ia melaksanakan profesi keguruannya dengan penuh kecintaan, penuh penghayatan, penuh semangat, dan dedikasi yang tinggi bagi institusi maupun organisasi profesi dan bagi bangsa dan negaranya karena tujuan yang lebih dari sekedar kebahagian duniawi, akan tetapi mencapai kepada tujuan duniawi. ${ }^{28}$

Ketiga, memiliki moral and ethics capacity. Maksudnya guru profesonal adalah guru yang mampu menjadi setral identifikasi diri siswa. Dengan kehadirannya, siswa akan tertular oleh transinternalisasi (penghayatan) akhlak maupun kepribadian sang guru. ${ }^{29}$ Selain itu, etika dan akhlak mulia sebagai basis bagi peran dan fungsi yang dilaksanakannya dalam membangun kemajuan peradaban (civilzation) melalui pendidikan, baik pada dimensi lahir maupun batin.

Dan, keempat, yaitu memiliki emotional capacity. Maksudnya, guru profesional adalah generator bagi proses internalisasi nilai, pengetahuan, sikap dan keterampilan siswa. Ia juga mampu menjadi motivator bagi terimplementasikannya nilai-nilai yang telah diajarkan untuk dapat diaplikasikan dalam ranah empirik. ${ }^{30}$

\section{Implikasinya terhadap Pengembangan Profesionalisme Guru} Dalam Pendidikan Dasar Islam

Berdasarkan telaah historis penelitian tentang efektivitas keberhasilan guru dalam menjalankan tuas kependidikannya, Medley sebagaimana dikutip Muhajdir menemukan beberapa asumsi keberhasilan guru yang pada gilirannya dijadikan titik tolak dala pengembangannya, yaitu: pertama, asumsi sukses guru tergantung

\footnotetext{
${ }^{27}$ H. Muhaimin, "Reorietasi Pengembangan, hlm. 104

${ }^{28}$ Ibid., hlm. 104-105

${ }^{29}$ Ibid., hlm. 105

${ }^{30}$ Ibid., hlm. 103
} 
pada penguasaan metode; kedua, asumsi sukses guru tergantung pada kepribadiannya; ketiga, asumsi sukses guru tergantung pada frekuensi dan intensitas aktivitas interaktif guru dengan siswa; dan keempat, asumsi bahwa apapun dasar dan alasannya penampilan gurulah yang terpenting sebagai tanda memiliki wawasan, ada indikator menguasai materi, ada indikator menguasai strategi belajar-mengajar dan lainnya. ${ }^{31}$ Dan, menurut Muhaimin, asumsi yang keempat ini memang lebih komprehensif sehingga dijadikan titik tolak dalam pengembangan guru, yang biasa disebut dengan PTKBK (Pendidikan Tenaga Kependidikan Berbasis Kompetensi) atau CBTE (Competency Based Teacher Education). ${ }^{32}$

Dan, untuk pengembangan guru profesional dalam pendidikan Islam di masa sekarang dan masa yang akan datang, dibutuhkan pengamatan secara cermat terhadap fenomena sosial dan kultur yang sedang aktual pada masa sekarang yang notabene juga merupakan bagian dari proses dan produk pendidikan. Sebagaimana diungkapkan Muhaimin, bahwa produk sistem pendidikan saat ini dinilai lebih menonjolkan kepentingan individual yang kurang menonjolkan aspek tanggungjawab masyarakat, atau lebih menekankan learning to know, learning to do, learning to be, dan kurang mengarah ke learning to live together. Sebagai imlikasinya, muncullah para individualis dan egoistis baru serta muncul masyarakat kepentingan (gezelschaft), sehingga yang tampak di permukaan adalah timbulnya konflik kepentingan-kepentingan, baik kepentingan individu, kelompok agama, etnis, politik maupun kepentingankepentingan lainnya, sedangkan nilai-nilai kooperatif dan kolaboratif sebagai karakteristik dari masyarakat Indonesa, pada khususnya, dan umat Islam pada umumnya, sudah mulai ditinggalkan. ${ }^{33}$

Kamrani Buseri juga mengungkapkan bahwa kekeliruan penghayatan potret diri guru yang ada selama ini harus diperbaiki sejalan dengan adanya harapan peningkatan peran guru dalam penumbuhan nilai-nilai Ilahiah di kalangan siswa. ${ }^{34}$ Oleh sebab itulah, dibutuhkan reorientasi pengembangan guru profesional yang

${ }^{31}$ Noeng Muhadjir, Imu Pendidikan dan Perubahan Sosial Teori Pendidikan Pelaku Sosial Kreatif (Yogyakarta: Rake Sarasin, 2000), hlm. 65

${ }^{32} \mathrm{H}$. Muhaimin, "Reorietasi Pengembangan, hlm. 105

${ }^{33} \mathrm{Ibid}$., hlm. 108

${ }^{34}$ H. Kamrani Buseri, Antologi Pendidikan Islam dan Dakwah: Pemikiran Praktis Kontemporer) (Yogyakarta: UII Press, 2003), hlm. 63 
bertolak dari pemahaman baru yang lebih holistik dan integratif tentang konsep guru profesional. Seperti konsep yang dikembangkan dalam paper ini, yaitu guru holistik-integralistik. Guru holistik-integralistik adalah sebuah konsep kreatif tentang sosok guru profesional yang dikembangkan dari konsep-konsep guru dalam khasanah pendidikan Islam yang meliputi mu'allim, murabbiy, ursyid, dan, mu'addib.

Adapun dari hasil telaah terhadap keempat istilah tersebut berhasil diramu menjadi struktur karakteristik guru holistikintegralistik dalam pendidikan Islam yang meliputi empat macam yaitu terdiri dari: pertama, memiliki intelectual and research capacity (kecakapan intelektual dan penelitian); kedua, memiliki spiritual capacity (kecakapan spiritual); ketiga, memiliki moral and ethics capacity (kecakapan moral dan etika), dan keempat, memiliki emotional capacity (kecakapan emosi).

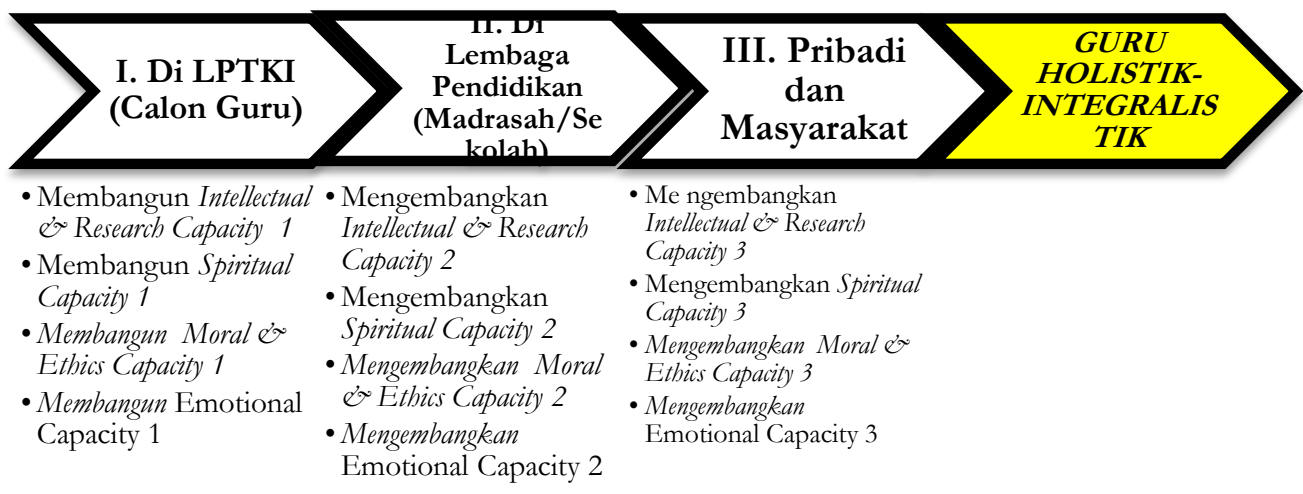

Apabila asumsi-asumsi tersebut dijadikan fokus perhatian, maka perlu dicarikan alternatif model pengembangan guru tersebut. Dan, dalam hal ini perlu dipahami bahwa untuk mengembangkan sosok guru holistik-integralistik bukanlah sesuatu hal yang sederhana, akan tetapi juga kompleks dan butuh proses karena melibatkan banyak unsur dalam kehidupan terutama yang terkait dengan profesi keguruannya tersebut. Selain itu, membutuhkan pula waktu yang tidak singkat. Gambar 2 Model Pengembangan Guru Holistik-Integralistik pada Tiga Wilayah Inti Kehidupan Guru

Ada tiga wilayah di mana pengembangan guru holistikintegralistik itu harus dilaksanakan, yaitu: pertama, wilayah Lembaga Pendidikan Tenaga Kependidikan Islam (LPTKI). Pentingnya 
wilayah ini bagi pengembangan profesionalisme guru tersebut adalah mengingat kata Akmal Hawi bahwa keprofesionalan seorang guru tidak lepas dari latar belakang akademik yang ditempuhnya sebelum menjadi guru. ${ }^{35}$ Semakin tinggi tingkat akademik seseorang biasanya menunjukkan lebih matang dalam berpikir, menganalisis berbagai macam permasalahan. Kemudian, dalam konteks mengajar, guru akan lebih memiliki kreativitas menggunakan metode yang diterapkan dalam proses pembelajaran sehingga tidak monoton dan siswa lebih antusias mengikutinya.

Dalam konteks di LPTKI maka proses penyiapan guru holistik-integralistik dapat bertolak dari beberapa pandangan sebagai berikut: ${ }^{36}$

a. Perlu memposisikan mahasiswa (calon guru) sebagai "santri" di LPTKI

Tujuan kegiatan ini adalah guna membina seperangkat kepribadian yang terkait dengan model atau sentral identifikasi diri atau mejadi pusat anutan dan teladan serta konsultan bagi peserta didiknya. Sebagai santri, ia akan berusaha meneladani dan mengikuti (dengan dibarengi argumentasi dan reasoning yang kokoh serta pandangan yang adil) jejak dosen-dosennya, terutama dari segi etos belajarnya, etos mengajarnya, etos pengembangan keilmuannya, dedikasinya, maupun etos amaliah ibadahnya dan perilaku-sehari-harinya. Implikasinya, LPTKI harus menyiapkan lingkungan yang kondusif bagi terwujudnya transinternalisasi nilai-nilai dan berbagai etos tersebut.

b. Perlu memposisikan mahasiswa (calon guru) sebagai thalib al'ilm di LPTKI

Maksudnya, kehadiran mahasiswa LPTKI adalah untuk mengajukan permohonan atau melamar keilmuan para dosennya atau seperangkat keilmuan yang dikembangkan di LPTKI. Dengan demikian, implikasinya LPTKI harus mampu memberikan pelayanan terhadap thalib alilm secara profesional. Namun, profesional bukan sekedar bermakna kegiatan mencari nafkah, akan tetapi mencakup calling profesion, yaitu panggilan atas pernyataan janji yang diucapkan di muka umum untuk ikut berkhidmat guna merealisasi terwujudnya nilai mulia yang

35 Akmal Hawi, Kompetensi Guru PAI (Palembang: IAIN Raden Fatah, 2005), hlm. 99

${ }^{36}$ H. Muhaimin, "Reorietasi Pengembangan, hlm. 109 
diamanatkan Tuhan dalam masyarakat melalui usaha keras dan cerdas.

c. Perlu menciptakan interaksi mendidik di LPTKI terutama antara pendidik dengan mahasiswa, atau antara karyawan dengan mahasiswa, dan atau antara mahasiswa dengan mahasiswa. Pendidikan Islam adalah upaya pengembangan pandangan hidup Islami yang dikembangkan dalam sikap hidup dan diwujudkan dalam keterampilan hidup. Dan bertolak dari pandangan ini, maka para tenaga pustakawan, laboran, karyawan admnistrasi, pesuruh dan lainnya yang bekerja di LPTKI , perlu diberi berbagai pembekalan yang memungkinkan untuk dapat membantu menciptakan konteks atau suasana yang menunjang pengembangan pandangan hidup Islami yang dikembangkan dalam sikap hidup dan diwujudkan dalam keterampilan hidup sehari-hari.

Kedua, yaitu pada wilayah lembaga pendidikan tempat guru bertugas. Pengembangan guru holistik-integralistik pada wilayah ini terutama dilakukan oleh kepala sekolah, penelitian sekolah, pengawas serta pembinaan lainnya untuk meningkatkan proses dan hasil belajar- mengajar yang akan diterapkaoleh guru tersebut. ${ }^{37}$ Adapun beberapa pandangan yang dapat dilakukan untuk mengembangkan profesionalisme guru sebagai guru holistikintegralistik sebagai berikut:

a. Lembaga (madrasah/sekolah) perlu memberikan kesempatan dan media yang memadai serta berkeadilan bagi semua guru, baik melalui studi lanjut ke jenjang pendidikan yang lebh tinggi, pengiriman guru ke kegiatan workshop, seminar, diklat, atau pelatihan untuk pengembangan profesionalismenya, dan lain sebagainya.

b. Mendorong para guru menerapkan cara kerja ilmiah dalam melaksanakan tugas keprofesionalannya. Maksudnya, melatih dan membiasakan guru untuk memecahkan setiap problem pengajaran dengan riset atau eksperiman (seperti melalui Penelitian Tindakan Kelas), bukan sekedar try and error.

c. Perlunya membangun wahana diskusi dan sharing ide, gagasan, atau temuan riset antar guru, baik itu antar guru dalam satu madrasah, atau antar guru antar madrasah atau bahkan antar guru madrasah dengan guru di sekolah. Hal ini dapat pula

${ }^{37}$ Akmal Hawi, Kompetensi Guru..., hlm. 85-86 
dilakukan dengan melatih dan membiasakan guru untuk gemar menulis dan berbaga ide atau hasil temuan penelitian melalui karya tulis ilmiah, seperti dalam bentuk penerbitan jurnal, buku, ataupun artikel di surat kabar.

d. Madrasah atau sekolah perlu membangun sebuah jejaring dengan LPTKI dalam kaitannya dengan pengembangan profesionalisme guru (baik untuk peningkatan pengetahuan filosofis maupun teoritis guru, atau sebagai laboraturium pendidikan, atau sebagai tempat riset yang berguna untuk mendapatkan evaluasi terhadap proses pembelajaran yang selama ini telah dilaksanakan (secara gratis).

e. Perlu membangun budaya dan iklim kerja yang positif dan religius dalam berbagai aspek kegiatan di sekolah, baik dalam konteks kegiatan belajar-mengajar, kegiatan manajerial, kegiatan sosial lainnya, seperti dengan menciptakan budaya disiplin pada kinerja guru dan karyawan terlebih dahulu, membangun budaya membaca dan menulis kepada semua guru (atau jika diperlukan maka bisa dengan mengadakan jam wajib baca atau wajib menulis bagi guru), mengadakan kegiatan shalat jama'ah, kultum setiap sehabis shalat berjamaah, shalat dhuha, membiasakan mengucapkan salam, berpakaian secara sopan dan rapi, membangun adab bertutur kata dan bergaul yang baik antara sesama guru atau guru dengan kepala madrasah atau guru degan pegawai atau guru dengan siswa. Dan, tidak kalah pentingnya dari semua itu adalah perlunya membangun keteladanan yang dimulai dari kepala madrasah dan guru senior. Dengan demikian, guru-guru muda bisa mengikuti jejak dan sifat maupun sikap positif dan religius dari kepala maupun guruguru seniornya.

f. Perlu membangun semangat dan kemauan yang tinggi kepada semua guru untuk berkemajuan. Hal ini dapat dilakukan dengan selalu me-recharge semangat dan daya juang guru baik dalam hal untuk pendidikan lanjut (hingga S-3), ${ }^{38}$ continouse improvement, dan terbuka terhadap kritik dan masukan dari berbagai pihak.

${ }^{38} \mathrm{Hal}$ ini didasari oleh fakta bahwa di negara-negara maju, lembaga pendidikan dasar maupun menengah itu tidak sekedar hanya diajar oleh guru-guru yang berkualifikasi pendidikan S-1, namun rata-rata sudah S-2 bahkan S-3. Lihat Sutrisno, Pembaharuan dalam Pengembangan Pendidikan Islam: Membentuk. Insan Kamil yang Sukses dan Berkualitas (Yogyakarta: Fadilatama, 2011), hlm. 73 
Misalnya dengan mengadakan pertemuan rutin antara kepala sekolah dengan semua guru secara kontinyu untuk melihat progresifitas perkembangan guru, baik dalam hal pekerjaannya maupun pengembangan diri yang telah dilakukannya. Upayakan dilakukan paling tidak dua kali dalam setiap bulannya. Adapun yang lebih efektif jika pemberian energi dan semangat baru itu selalu dilakukan secara rutin setiap minggu sekali. Dalam kegiatan ini, segala persoalan dan kendala yang dihadapi oleh guru bisa dibahas untuk dicari solusinya. Dan, jika dimungkinkan maka akan sangat baik jika mendatangkan para pakar dibidangnya yang telah dikenal sukses menekuni bidangnya tersebut untuk memangkitkan semangat dan motivasi guru dengan berguru kepada orang-orang yang telah sukses itu kemudian bisa diaplikasikan dalam profesi keguruannya. Ini mungkin dapat dilakukan sebulan sekali atau jika dana tidak memungkinkan satu semester bisa diadakan satu kali atau paling tidak satu tahun sekali.

g. Perlunya menjalin semangat kekeluargaan yang tinggi. Maksudnya, untuk menjadi guru yang holisik-integralistik sebagai guru profesional dalam pendidikan Islam maka dibutuhkan kecerdasan emosi yang tinggi. Dalam artian, guru harus menyadari keberadaannya sangat terkait dengan keberadaan orang lain. Dan, guru juga harus tahu siapa dirinya sendiri dan seperti apa potensi dirinya itu. Atau dengan kata lain, guru harus memiliki kecerdasan interpersonal dan intrapersonal. Dengan demikian, perlu dibangun budaya saling memahami, budaya saling memberi nasihat, budaya saling tolong-menolong, saling mendukung, saling mengingatkan, dan budaya bekerjasama di lingkungan sekolah maupun lingkungan keluarga besar organisasi keprofesiannya. Hal ini penting, karena jika guru telah mampu menjadi pribadi yang cerdas secara interpersonal maupun intrapersonal kemudian juga sehat jiwanya (bahagia) maka nilai-nilai kebaikan itu akan mudah tertular (transinternalisasi) kepada siswa.

Adapun wilayah lain yang tidak kalah penting dan perlu menjadi sorotan dalam pengembangan profesionalisme guru untuk menjadi guru holistik-integralistik, yaitu wilayah pribadi dan masyarakat. Inilah wilayah ketiga yang dimaksudkan dalam tiga wilayah pengembangan guru holistik- 
integralistik sebagai guru profesional dalam pendidikan Islam pada paper ini, di mana dua lainnya telah disebutkan dan dijelaskan sebelumnya.

Pentingnya wilayah ini untuk menjadi salah satu area penting dalam pengembangan guru holistik-integralistik adalah didasari pandangan Kamrani Buseri yang menyatakan bahwa guru merupakan bagian dari masyarakat..$^{39}$ Kemudian juga pandangan Prayitno yang menyatakan bahwa pada hakikatnya manusia itu untuk pengembangan diri dan kehidupan selanjutnya, maka ia dilengkapi dengan dimensi-dimensi kemanusiaan yang terdir dari dimensi kefitrahan, dimensi keindividualan, dimensi kesosialan, dimensi kesusilaan, dan dimensi keberagamaan. Dan, secara spesifik, dalam dimensi kesosialan tersebut, ungkap Prayitno, bahwa individu menjalin komunikasi dan hubungan dengan individu lain. Di samping itu, individu juga menggalang kebersamaan dengan individu lain dalam berbagai bentuk, seperti persahabatan, keluarga, kumpulan, dan organisasi. ${ }^{40}$

Pada wilayah pribadi dan masyarakat, berdasarkan karaktersistik guru holistik-integralistik yang disebutkan di depan maka pengembangannya dapat dilakukan dengan menggunakan beberapa pandangan sebagai berikut:

a. Untuk membangun intellectual and research capacity maka guru (muda/yunior) atau calon guru hendaknya aktif dalam berbagai kegiatan dan kajian ilmiah yang ada atau diselenggarakan oleh masyarakat. Biasanya kajian-kajian seperti ini dilakukan di luar jam kerja atau hari libur. Kegiatan-kegiatana seperti ini biasanya dilakukan oleh organisasi pelajar atau mahasiswa, lembaga swadaya masyarakat, atau organisasi sosial masyarakat. Bentuknya bisa berupa pelatihan ICT, pelatihan pengembangan diri, seminar atau workshop tentang isu-isu aktual dalam ranah politik, sosial, budaya, agama, maupun pendidikan. Selain itu, guru atau calon harus aktif melihat dan mengambil peluang berbagai beasiswa studi ataupu dana hibah penelitian. Terakhir, yaitu guru atau calon guru hendaknya mulai belajar menulis buku atau artikel di surat kabar. Dengan mendesiminasikan, menyebarluaskan, membagikan, atau mengkomunikasikan ilmu pengetahuan, ide, atau gagasan keilmuan bagi masyarakat maka pengetahuan guru pun akan semakin kaya. Selain itu, gagasan yang baik akan berguna bagi masyarakat.

${ }^{39}$ Kamrani Buseri, Antologi Pendidikan..., hlm. 64

40 Prayitno, Dasar Teori dan Praksis Pendidikan (Jakarta: Grasindo, 2009), hlm. 
b. Untuk membangun spiritual capacity, maka para guru perlu mengembangkan pemahaman keagamaan yang tidak sekedar normatif-dogmatis (atau sekedar ritualistik dan simbolik) akan tetapi harus mulai diarahkan kepada yang kontekstual dan holistik. Rasio atau akal hendaknya dimaksimalkan penggunaannya dalam memahami agama. Sehingga agama tidak sekedar sebatas keyakinan yang membabi-buta. Guru ataupun calon guru dapat mengikuti kajian-kajian keagamaan atau membaca buku-buku yang mencerahkan, yang tidak sekedar membahas persoalan agama dari sisi yang normatif saja akan tetapi juga diarahkan kepada sisi yang aplikatif dan kontekstual dalam kehidupan. Maksudnya, agama tidak sekedar dipahami kulitnya akan tetapi masuk hingga inti sarinya. Agama tidak hanya untuk ritual akan tetapi juga untuk kehidupan seutuhnya. Adapun langkah lain yang bisa ditempuh untuk membangun spiritual capacity, yaitu dengan bersikap kritis dan terbuka terhadap ilmu-ilmu baru dan tidak pernah berhenti untuk mengkaji agama. Kemudian, menjalankan ritual agama secara rutin, kontinyu, dan disiplin. Selain itu, guru harus juga menerapkan agama dalam kehiduannya secara utuh. Dan, menjadikan agama sebagai worldview dan filsafat hidup.

c. Untuk membangun moral and ethics capacity, maka guru ataupun calon guru hendaknya aktif dalam berbagai kegiatan sosial di masyarakat. Guru hendaknya bisa mengaplikasikan nilai-nilai pendidikan yang telah dipelajari dan dimilikinya untuk diaplikasikan di kehidupan sehari-hari dan masyarakat. Selain itu, langkah riil lain yang perlu dilakukan guru atau calon guru untuk membangun moral and ethics capacity adalah menjunjung tinggi aturan norma-norma kehidupan di masyarakat yang dilakukan dengan dengan memahami dan menghormatinya. Guru hendaknya menjadi teladan dan agent of change di masyarakat. Guru juga harus menjadi problem solver bagi persoalan di masyarakatnya. Cara lain yang bisa dilakukan guru yaitu dengan membaca buku-buku moral dan etika, mengikuti seminar pendidikan karakter, atau menjadi pembicara dalam seminar tentang pendidikan karakter, moralitas ataupun etika.

d. Untuk membangun emotional capacity, maka guru atau calon guru perlu berlatih untuk membiasakan diri berpikir positif, bertindak secara positif, dan senantiasa punya semangat tinggi. 
Secara individual, guru atau calon guru dapat memulainya dengan menerapkan sikap dan pola berpikir yang positif dalam kehidupan sehari-hari. Dengan sikap dan berpikir positif, energi positif akan masuk dan membakar semangat mereka untuk selalu semangat dan punya daya juang yang tinggi. Hal ini perlu latihan setiap hari. Selain itu, penting ditanamkan dalam diri setiap guru atau calon guru yaitu kesabaran. Karena, kesabaran dan ketekunan dalam membimbing peserta didik melalui proses yang panjang pendidikan di sekolah adalah kunci keberhasilannya. Cara lainnya, yaitu menjadi guru atau calon guru yang siap menjadi pelayan publik. Harus dipahami memang bahwa dalam masyarakat kita, guru masih dianggap sebagai orang yang mampu mengatasi berbagai masalah di masyarakat (terutama di pedesaan). Sehingga apapun persoalan di masyarakat, gurulah yang dipandang mampu menyelesaikannya. Dalam kondisi seperti ini, untuk menjadi guru holistik-integralistik maka guru bisa memanfaatkan kondisi tersebut untuk berlatih dan mengembangkan diri menjadi pelayan publik yang baik, yang siap setiap saat untuk membantu kebutuhan warga masyarakat (yang dirasa mampu), atau senantiasa bersedia memberikan bantuan solusi bagi persoalan di masyarakat secara tulus. Hal ini jika telah dimiliki oleh seorang guru maka tidak akan sulit bagi seorang guru atau calon guru untuk mendorong dan memotivasi peserta didik agar belajar cerdas dan belajar dengan keras. Guru seperti ini juga akan mudah mendorong peserta didik untuk disiplin. Ia juga tidak akan kesulitan untuk menularkan akhlak mulia maupun nilai-nilai Ilahiah kepada siswa, karena ia mampu memahami kebutuhan siswa dan dapat melayani siswa dengan baik dan tulus. Selain itu, dalam konteks di masyarakat emotional capacity dapat dibangun dengan mengikuti training-training publik relation, seminar pengembangan diri, training capacity building, seminar tentang kepemimpinan, dan lain sebagainya. Atau bisa pula hal itu dilakukan dengan membaca buku, artikel, dan lain sebagainya.

Demikianlah, model pengembangan profesionalisme guru untuk menjadi guru holistik-integralistik yang meliputi tiga wilayah yaitu pada wilayah Lembaga Pendidikan Tenaga Kependidikan Islam, pada wilayah lembaga pendidikan tempat mengajar, dan terakhir pada wilayah pribadi dan 
masyarakat. Ketiga-ketiganya adalah sebuah unsur yang padu. Sehingga ketika ingin mengembangka guru holistik-integralistik, maka perlu diupayakan pengembangan profesionalisme pada ketiga wilayah tersebut. Dengan kata lain, pola pengembangannya tidak bisa dipisah-pisah, namun harus utuh dan saling terkait. Dengan cara seperti itulah model yang diharapkan benar-benar dapat mengembangkan sosok guru holistikintegralistik sebagai guru profesional dalam pendidikan Islam. 


\section{PENUTUP}

Dari uraian di atas, maka dapat disusun kesimpulan sebagai berikut: pertama, berdasarkan kajian terhadap konsep-konsep guru yang lazim digunakan dalam pendidikan Islam (terutama yang bersumber dari al-Qur'an dan al-Hadits) yang meliputi mu'allim, murabbiy, mursyid, dan, mu'addib dengan berbagai penjelasannya dapat ditarik sebuah meaning of creativity tentang konsep baru guru profesional dalam pendidikan Islam yaitu guru holistikintegralistik.

Kedua, guru holistik-integralistik adalah sosok guru profesional di Madrasah Ibtidaiyah yang dibangun dari empat karakteristik utama yang utuh dan saling terkait, meliputi intellectual and research capacity (kecakapan inteletual dan riset), spiritual capacity (kecakapan spiritual), moral and ethic capacity (kecakapan moral dan etika), dan emotional capacity (kecakapan emosi).

Ketiga, implikasi pandangan baru tentang guru profesional dalam pendidikan dasar Islam tersebut (yaitu guru holistik-integralistik) adalah bahwa perlu dilakukannya reorientasi baru dalam pengembangan profesionalisme guru dalam pendidikan Islam. Dan, merujuk kepada keempat karakteristik guru holistik-integralistik maka orientasi pengembangan guru profesional dalam pendidikan Islam perlu diupayakan pada tiga wilayah inti yang tidak bisa dipisahkan-pisahkan, yaitu pada lembaga pendidikan tenaga kependidikan, kemudian pada lembaga pendidikan tempat mengajar (madrasah/sekolah), dan pada kehidupan pribadi dan masyarakat. 


\section{DAFTAR PUSTAKA}

Asmani, Jamal Ma'mur, 7 Tips Cerdas dan Efektif Lulus Sertifikasi Guru, Yogyakarta: Diva Press, 2010.

Buseri, H. Kamrani, Antologi Pendidikan Islam dan Dakwah: Pemikiran Praktis Kontemporer), Yogyakarta: UII Press, 2003.

Djumransjah, H.M., dan Abdul Malik Kamrullah, Pendidikan Islam: Menggali Tradisi, Menegubkan Eksistensi, Malang: UIN-Malang Press, 2007.

Hawi, Akmal, Kompetensi Guru PAI, Palembang: IAIN Raden Fatah, 2005.

Indratno, A. Ferry T., Kurikulum yang Mencerdaskan: Visi 2030 dan Pendidikan Alternatif, Jakarta: Kompas Media Nusantara, 2008.

Lajnah Pentashih Mushaf A-Qur'an Departemen Agama Republik Indonesia, Al-Qur'an dan Terjemahannya, Bandung: Jumanatul 'Ali Art, 2005.

Muhadjir, Noeng (a), Ilmu Pendidikan dan Perubahan Sosial Teori Pendidikan Pelaku Sosial Kreatif, Yogyakarta: Rake Sarasin, 2000.

(b), Metodologi Penelitian: Paradigma Positivisme Objektif, Phenomenologi Interpretif, Logika Bahasa Platonis, Chomskyist, Hegelian \& Hermeneutik, Paradgma Studi Islam Matematik Recursion, Set-Theory \& Structura Equation Modelling dan Mixed Edisi VI Pengembangan 2011, Yogyakarta: Rake Sarasin, 2011.

Prastowo, Andi, "Profesionalitas Seksi Mapenda di Kabupaten Sleman dalam Peningkatan Mutu Pendidikan di Madrasah Ibtidaiyah", Tesis, Tidak Diterbitkan, Yogyakarta: Program Pascasarjana Magister Pendidikan Guru Madrasah Ibtidaiyah UIN Sunan Kalijaga Yogyakarta, 2010.

Prayitno, Dasar Teori dan Praksis Pendidikan, Jakarta: Grasindo, 2009.

Rahardjo (Ed.), H. Mudjia, Quo V adis Pendidikan Islam: Pembacaan Realitas Pendidikan Islam, Sosial dan Keagamaan, Malang: UIN-Malang Press, 2006.

Sa'ud, Udin Syaefudin , Pengembangan Profesi Guru, Bandung: Alfabeta, 2009.

Soltanera, CD Ensiklopedi Hadits Kitab 9 Imam, Lidwa Pustaka, 2010-2011.

Suharto, Toto, Filsafat Pendidikan Islam Edisi Baru, Yogyakarta: Ar-Ruzz Media, 2011.

Sutrisno, Pembaharuan dalam Pengembangan Pendidikan Islam: Membentuk Insan Kamil yang Sukses dan Berkualitas, Yogyakarta: Fadilatama, 2011.

Untung, Moh. Slamet, Muhammad Sang Pendidik, Semarang: Pustaka Rizki Putra bekerjasama dengan Program Pascasarjana IAIN Walisongo, 2005 